\title{
Reproductive biology of common snook Centropomus undecimalis (Perciformes: Centropomidae) in two tropical habitats
}

\author{
Martha A. Perera-García ${ }^{1}$, Manuel Mendoza-Carranza ${ }^{2}$, Wilfrido M. Contreras-Sánchez ${ }^{3}$, \\ Maricela Huerta-Ortíz ${ }^{3}$ \& Eunice Pérez-Sánchez ${ }^{3}$ \\ 1. División Académica Multidisciplinaria de los Ríos, Universidad Juárez Autónoma de Tabasco, Col. Solidaridad S/N, \\ C.P. 86901, Tenosique, Tabasco, México; martha.perera@damr.ujat.mx \\ 2. El Colegio de la Frontera Sur (ECOSUR), Carretera Villahermosa/Reforma, Kilómetro 15.5, Ranchería Guineo 2a. \\ Sección, C.P. 86280, Villahermosa, Tabasco, México; mcarranza@ecosur.mx \\ 3. División Académica de Ciencias Biológicas, Universidad Juárez Autónoma de Tabasco, 967 Villahermosa, Tabasco, \\ México; contrerw@hotmail.com
}

Received 23-IV-2010. Corrected 08-X-2010. Accepted 08-XI-2010.

\begin{abstract}
In Southeastern Mexico, Centropomus undecimalis is an important fish species of sport and commercial fisheries for coastal and riverine communities. Fisheries along rivers and coasts depend on migratory habits of this species, and these movements are probably related to reproduction. In spite of its economic importance, few studies have been conducted focusing on its reproductive biology, and this research aims to analyze these habits. Samples (fork length, somatic and gonads weight, and macroscopic maturity stages) were obtained from organisms collected by fishermen from the largest fishing cooperatives along the coastal and riverine areas of Tabasco, from July 2006 to March 2008. Fish size ranged from 34 to $112 \mathrm{~cm}$ fork length, with an average age of 6.42 years for males and 9.12 years for females. In riverine areas, fish sizes ranged from 30 to $85 \mathrm{~cm}$ and the average age was 5.5 years for males and 6.6 years for females. Significant differences were recorded between lengths of males and females from the two areas (Kruskal-Wallis, $\mathrm{p}<0.05$ ). The male:female ratio was 1:0.68 in the coast, and 1:0.16 in riverine areas. The length-weight relationship did not vary between both sexes among areas (ANCOVA, $\mathrm{p}>0.05$ ). A curve for eviscerated weight was calculated for both sexes, for coastal fishes $\mathrm{SW}=0.0059(\mathrm{FL})^{3.07}$, and the riverine ones $\mathrm{SW}=0.0086(\mathrm{FL})^{2.98}$, with an isometric growth $(\mathrm{b}=3)$. The period of maximum reproduction was from July to August, with temperatures of 28 to $30^{\circ} \mathrm{C}$. A significant correlation between the gonadosomatic index (GSI) and rainfall was recorded for samples of both males and females from coastal areas $(r=0.63, r=0.70)$ whereas only one positive correlation was recorded for riverine females $(r=0.57)$. The size at first maturity $\left(\mathrm{L}_{50}\right)$ was estimated at $60 \mathrm{~cm}$ and $80 \mathrm{~cm}(\mathrm{FL})$, corresponding to 5.5 and 8.5 years of age, for males and females, respectively. An important proportion of mature females of eight years and older, suggests that these ages contribute significantly to the reproductive biomass. The results indicate that due to changes in the exploitation period, we recommend to protect populations of the common snook. Rev. Biol. Trop. 59 (2): 669-681. Epub 2011 June 01.
\end{abstract}

Key words: migration, reproduction, size at maturity, Centropomus undecimalis.

The common snook Centropomus undecimalis is a tropical protandric hermaphrodite fish, with euryhaline and diadromous habits (Taylor et al. 2000, Tavares \& Luque 2003, Muller \& Taylor 2006). It is distributed from the Western coast of the Atlantic Ocean in North America (Florida, USA) to South America (Rio de Janeiro, Brazil), including the Gulf of Mexico and the Caribbean Sea (Brennan et al. 2006, Zarza-Meza et al. 2006). A close relationship with rivers and coastal lagoons has been observed for the common snook throughout its distribution range (Peters et al. 1998, Aliaume et al. 2005). These systems are used by the species for its periodic migrations when it feeds, grows and reproduces (Stevens et al. 
2007). In Southeastern Mexico, C. undecimalis is an important species for sport fishing and commercial fisheries for people from coastal and riverine communities (Muller \& Taylor 2006, Perera-García et al. 2008), due to its migratory habits and its size of up to $130 \mathrm{~cm}$ (Tringali \& Leber 1999, Perera-García et al. 2008). In Tabasco, the official catch data for common snook date from 1978, maximum catch were recorded in the last five years of the analyzed time series reaching up to 2800 metric tons (SAGARPA 2008, Fig. 1).

Despite its economic importance, few studies have focused on various aspects of the biology of the common snook. Previous studies have established the migrations of the species, associated with massive spawnings at river mouths (Lau \& Shafland 1982, Tucker \& Campbell 1988, Peters et al. 1998, Taylor et al. 2000, Lowerre-Barbieri et al. 2003). Centropomus undecimalis spawning along the Tabasco coast has been recorded once per year between May and July, when migrations among estuaries and freshwater tributaries take place (Caballero 2003, Perera-García et al. 2008). For this reason, the main purpose of this study was to describe the reproductive biology of $C$. undecimalis based on samplings from the coastal Gulf of
Mexico and the riverine region of the Usumacinta River in Tabasco, and examine the potential relationship between the monthly gonad development and water temperature and rainfall.

\section{MATERIALS AND METHODS}

Sampling site. Specimens of C. undecimalis were obtained from the stocks collected by the artisanal fishery from the coastal area of Barra el Bosque (18 $36^{\prime} 52^{\prime \prime} \mathrm{N}-92^{\circ} 41^{\prime} 07^{\prime}$ 'W) and Barra San Pedro (18 $38^{\prime} 59^{\prime \prime}$ N - 92 $41^{\circ}$ '07' $\mathrm{W})$, and the riverine area of Tres Brazos $\left(18^{\circ} 23^{\prime} 50^{\prime \prime} \mathrm{N}-92^{\circ} 38^{\prime} 52^{\prime \prime} \mathrm{W}\right)$ and San Pedro

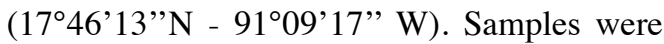
obtained monthly from July 2006 to March 2008, (total of $\mathrm{N}=790$; coastal area $\mathrm{n}=323$, riverine area $\mathrm{n}=467$ ).

Fork length (FL, cm), somatic weight (SW, g) were measured, and sagittal otoliths were removed, sex and stage of gonadic maturity were recorded for each individual. Sex and sexual maturity were determined using the morphological characteristics and color of the gonad, following the criteria established by Vazzoler (1996), Peters et al. (1998) and Taylor et al. (1998) for sequential spawners (Table 1).

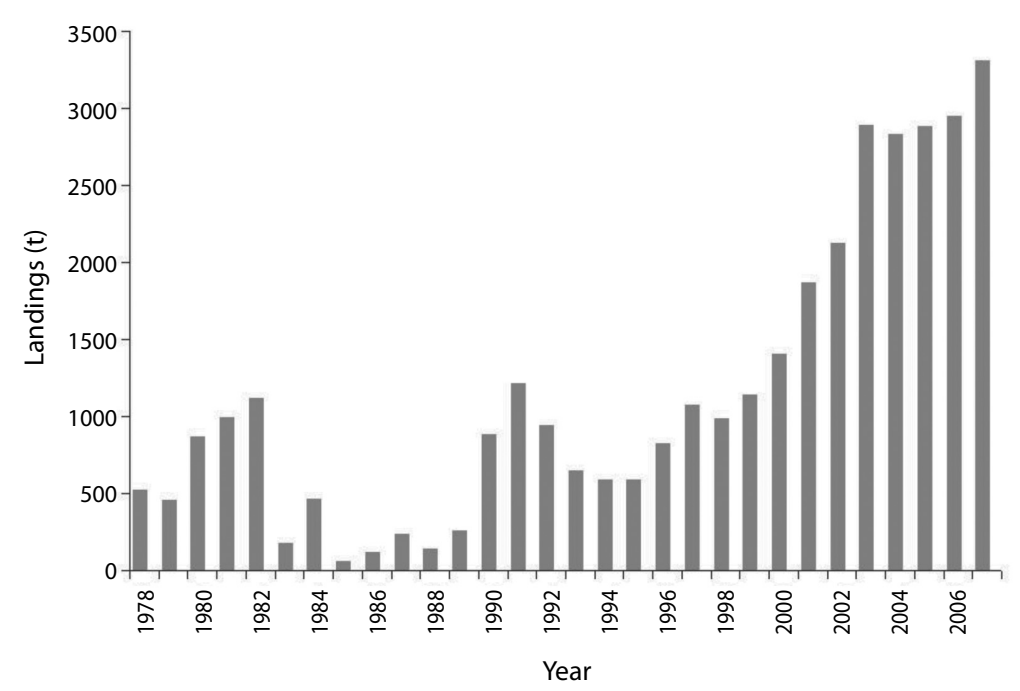

Fig. 1. Comercial landings of C. undecimalis, Tabasco, Mexico. 
TABLE 1

Macroscopic description of gonadal development stages of $C$. undecimalis

Stage

Indefinite (I)

Inmature (II)

Maturing process (III)

Mature (IV)

Spawning (V)

Restin (VI)

\section{Characteristics}

The sex glands are very thin filaments, it is not possible to differentiate males from females.

Ovaries thin sexing is possible. Initiates the development of the gonads, the ovaries are pink, translucent eggs are not visible to the naked eye. Testes in white ribbon, both gonads attached to orange-brown tissue.

Ovaries occupy half of the abdominal cavity. Gonadic glands are distinct between sexes. The ovaries are granular, pinkish-yellow color, small eggs and opaque, with lots of connective tissue. Testicles are of an ivory color, posterior side is wider than the anterior side. It is a long stage.

Ovaries occupy two thirds of the abdominal cavity. The development of the glands is advanced. Ovaries are pinkish orange. Large and transparent eggs are present. Sexual products of females and males are expelled when the specimen abdomen is pressed. Testes are whitish and triangular in its entirety. Short-term phase.

Ovaries occupy the whole abdominal cavity. Ovaries are large, plump and bright orange colored, sexual products readily to be expelled. Well-developed veins irrigating the entire gonad. Pearly white testes, sperm comes out when press lightly.

Ovaries are enlarged and flabby, the product has been expelled. Sex glands are swollen and brownish-gray. Residual eggs are absorbed.

The fork length-somatic weight relationship (Ricker 1975) was calculated separately for the two sexes after the mathematical relationship: $\mathrm{SW}=\mathrm{aFL}^{\mathrm{b}}$, where: $\mathrm{SW}$ is the somatic weight, $a$ is the intercept (initial growth coefficient or condition factor), FL is the fork length, and $b$ is the slope (growth coefficient, that indicates the isometric or allometric growth).

Monthly sex ratios were calculated for the different stages of maturity. Gonadosomatic index (GSI) was calculated according to Rodríguez-Gutiérrez (1992): GSI=GW/SW*100, where GW is the gonad weight and SW is the somatic weight of each individual.

The average size and age at sexual maturity defined as the size and age at which $50 \%$ of the fish are sexually mature $\left(\mathrm{L}_{50}\right.$ and $\left.\mathrm{A}_{50}\right)$, and at which all organisms are capable of actively participate in the reproductive process $\left(\mathrm{L}_{100}\right.$ and $\left.\mathrm{A}_{100}\right)$, was obtained from the common snook male and female accumulated relative frequencies of macroscopically determined maturity stages between II and V (Vazzoler 1996, Luksenburg \& Pedersen, 2002). The values were smoothed with the logistic equation of Sparre \& Venema (1998):

$$
\mathrm{S}(\mathrm{L})=1 /\left(1+\mathrm{e}^{(\mathrm{S} 1-\mathrm{S} 2 * \mathrm{Fl})}\right)
$$

where $\mathrm{S}(\mathrm{L})$ is the accumulated relative frequency, S1 is the constant or intercept (a), S2 is the constant or slope (b), and FL is the fork length $(\mathrm{cm})$.

The age was determined by interpreting growth rings on the otoliths. A low speed Buehler® IsoMet ${ }^{\circledR} 1000$ saw was used to cut sections approximately $0.5 \mathrm{~mm}$ thick (Taylor $e t$ al. 2000). Sections were mounted onto clean slides with Crystal Bond ${ }^{\mathrm{TM}}$ \#509 thermoplastic cement (Electron Microscopy Supply, Inc.), polished, and viewed under transmitted light using a stereoscopic microscope, fitted with a Cannon ${ }^{\mathrm{TM}}$ Power Shot G6 digital camera. Enlarged 7.5 megapixel images were used to enumerate the age marks by two independent readers. A translucent band and an adjacent opaque band were assumed to represent one year of growth (Taylor et al. 2000, Campana 2005). 
Each sectioned otolith was read twice and only coincident readings were accepted (Beamish \& McFarlane 1983, Taylor et al. 2000).

Monthly mean between fork lengths of males and females were compared with a Kruskal-Wallis non-parametric analysis of variance (Zar 1999, Sokal \& Rohlf 1996). A multiple correlation and a covariance (ANCOVA) analysis were applied to the FL-SW regressions to assess differences between sexes (Gulland 1983, Sparre \& Venema 1998). The allometric growth equations were obtained with logarithmic transformations (Zar 1999, Sokal \& Rohlf 1996). A t-test ( $\alpha=0.05)$ was used to the value of the slope $b$ to determine the type of growth (Ibáñez \& Fernández 2006). Monthly GSI, water temperature and the rainfall, were examined with a cross-correlation analysis to examine their relationship (Pyper \& Peterman 1998). Besides, a Chi-square $\left(X^{2}\right)$ was utilized to compare monthly sex ratio by length class (Underwood 1997).

\section{RESULTS}

Size structure. The size range of common snook collected along the coastal area was 34 to $112 \mathrm{~cm} \mathrm{FL} \mathrm{(Fig.} \mathrm{2A).} \mathrm{The} \mathrm{mini-}$ mum, average and maximum lengths recorded were $33.7,69.1$ and $94.5 \mathrm{~cm}$ for males, and

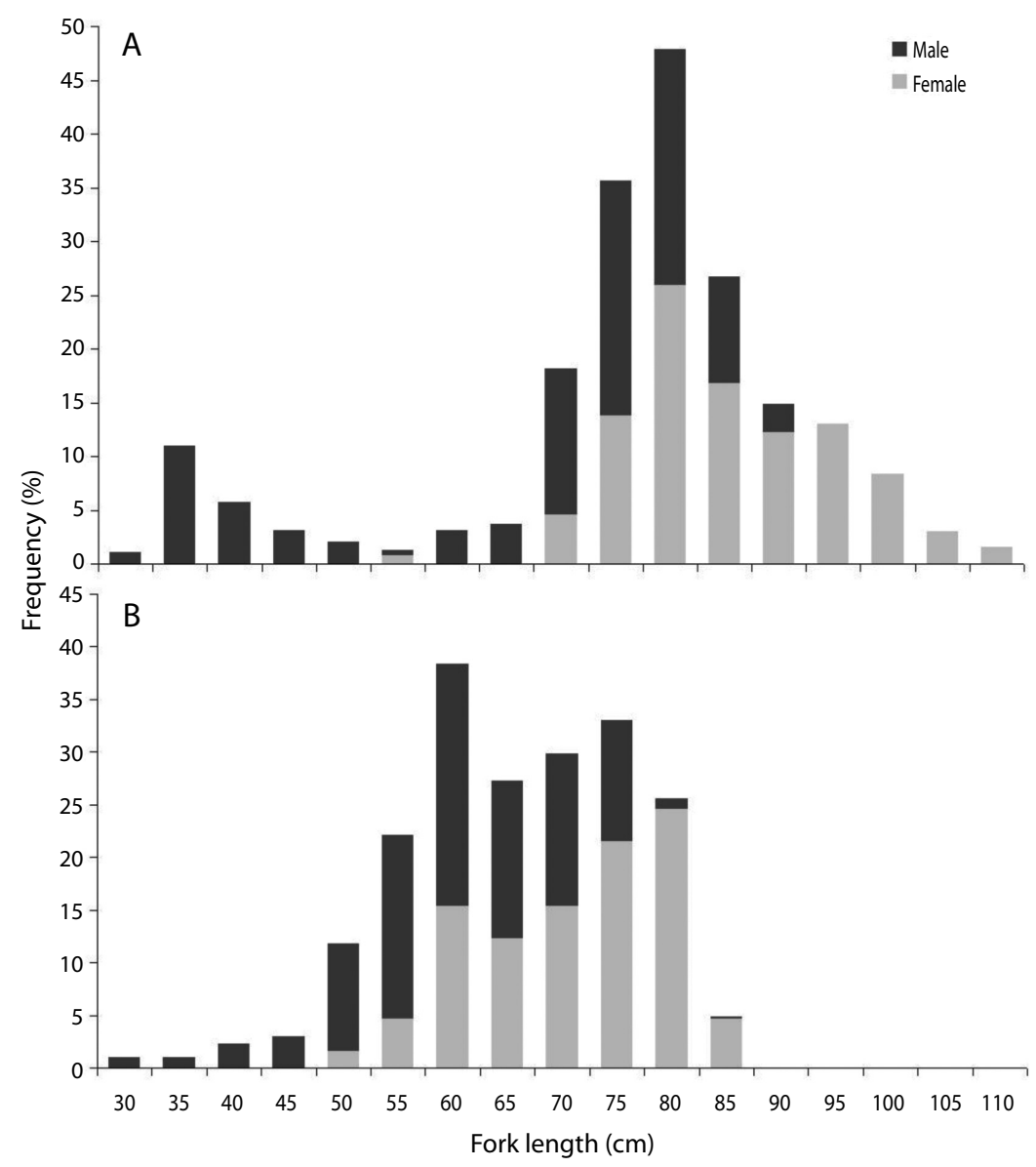

Fig. 2. Size frequency distributions for C. undecimalis females and males in the coastal (A) and riverine (B) areas, Tabasco, Mexico. 
$58.2,88.4$ and $111.5 \mathrm{~cm}$ for females, respectively. The size range of specimens from the riverine area was from 30 to $85 \mathrm{~cm}$ FL (Fig. 2B). The minimum, average and maximum lengths were $30,62.8$ and $88.5 \mathrm{~cm}$ for males, and $54.5,74$ and $88 \mathrm{~cm}$ for females, respectively. Female were significantly larger in both marine $(\mathrm{KW}=112.43, \mathrm{p}<0.05)$ and riverine $(\mathrm{KW}=49.52, \mathrm{p}<0.05)$ environments.

Length-weight relationship. Lengthweight relationship were not statistically different between the males and females for coastal (ANCOVA, $\mathrm{F}=1.84, \mathrm{p}>0.174$ ) and for riverine (ANCOVA, $\mathrm{F}=0.46, \mathrm{p}>0.493$ ) areas. Individual length-weight equations were: coastal females $\mathrm{SW}=0.0133(\mathrm{FL})^{2.90} ; \mathrm{r}^{2}=0.88$, coastal males, $\mathrm{SW}=0.0045(\mathrm{FL})^{3.14} ; \mathrm{r}^{2}=0.95$; and coastal both sexes, $\mathrm{SW}=0.0059(\mathrm{FL})^{3.07}$; riverine females $\mathrm{SW}=0.0071(\mathrm{FL})^{3.04} ; \mathrm{r}^{2}=0.85$; riverine males, $\mathrm{SW}=0.0098(\mathrm{FL})^{2.95} ; \mathrm{r}^{2}=0.90 ;$ and riverine both sexes $\mathrm{SW}=0.0086(\mathrm{FL})^{2.98}$. The $b$ value observed for both study areas was not different from three, confirming that the growth of $C$. undecimalis is isometric $(\mathrm{t}=1.63, \mathrm{p}>0.05)$.

Sex ratio. The males collected along the coast represented 59\% ( $\mathrm{n}=192)$ of the sampled organisms, and the females $41 \%(n=131)$. The overall ratio of male:female was 1.46:1, diverging significantly from $1: 1 .\left(X^{2}=61.09\right.$, $\mathrm{p}<0.001)$. The greatest proportions of males were observed in July (79\%), August (77\%) and November (93\%) of 2006, and in May (91\%) and December (70\%) of 2007; furthermore, females were observed during July (63\%) and August (73\%) of 2007. In the case of the riverine area, males represented $86 \%$ (402) and females $14 \%(65)$, with a male:female ratio of 6.18:1 which was different from the expected ratio of $1: 1 \quad\left(X^{2}=26.23, \mathrm{p}<0.001\right)$. Males dominated during the whole sampling period, with a greater number of females only in May $(53 \%)$ of 2007.

Sex ratio by length class in the coastal area for males showed significant differences $\left(X^{2}\right.$; $\mathrm{p}<0.05)$ between the $30-75 \mathrm{~cm}$ and the $90 \mathrm{~cm}$ $\mathrm{FL}$, and females of $70-75 \mathrm{~cm}$ and $90-110 \mathrm{~cm}$
FL (Fig. 3A). In the riverine area, significant differences were observed in the classes of $30-70$ and $80-85 \mathrm{~cm}$ FL for males, and females of $50-70$ and $80-85 \mathrm{~cm}$ FL (Fig. 3B).

Gonadosomatic index. For the coastal area, the monthly average of the GSI of males and females was similar, with greater values in July, August and September of 2006, and in July and August of 2007. The other months presented low values (Fig. 4A). The maximum GSI values of both sexes were correlated with water temperatures of 26 to $30^{\circ} \mathrm{C}$ (Fig. 4B). For the riverine area, the monthly GSI indicated no reproductive activity and no relationship with rainfall and temperature, showing that $C$. undecimalis reproduction does not occur in this riverine area.

The cross-correlation analysis showed a three month lag from maximum rainfall to maximum GSI for coastal males $(\mathrm{r}=0.63)$ and four months for females (r=0.70) (Fig. 5 A,B).

Distribution of sexual maturity stages. The largest number of the classified females and males of the coastal area presented stages II and III, and these were frequent in most sampling months. Most of mature females (stage IV) were observed in August 2006 (50\%) and June to July 2007 (33.3\%), and most of mature males were present in July 2006 (48.2\%), and from May (60\%) to July $(42.8 \%)$ of 2007. Stage V, which represents the maximum spawning period was observed for females in July 2006 (25\%), and in March (12.5\%), June (16.6\%) and August (12.5\%) 2007 (Fig. 6A), as well as for males in July 2006 (27.5\%) and July 2007 (14.2\%). The resting phase (VI, gonads without eggs) was observed in females in July (37.5\%), August (50\%) and December (36.3\%) 2006, also in February (22\%), March (25\%), June (33\%), July (16.6\%) and August (12.5\%) 2007. It was not possible to observe this phase in males (Fig. 6B).

In the case of the riverine area, advanced stages were not observed in either females or males. Stage II was predominant during the sampling period. Stage III was observed in the 

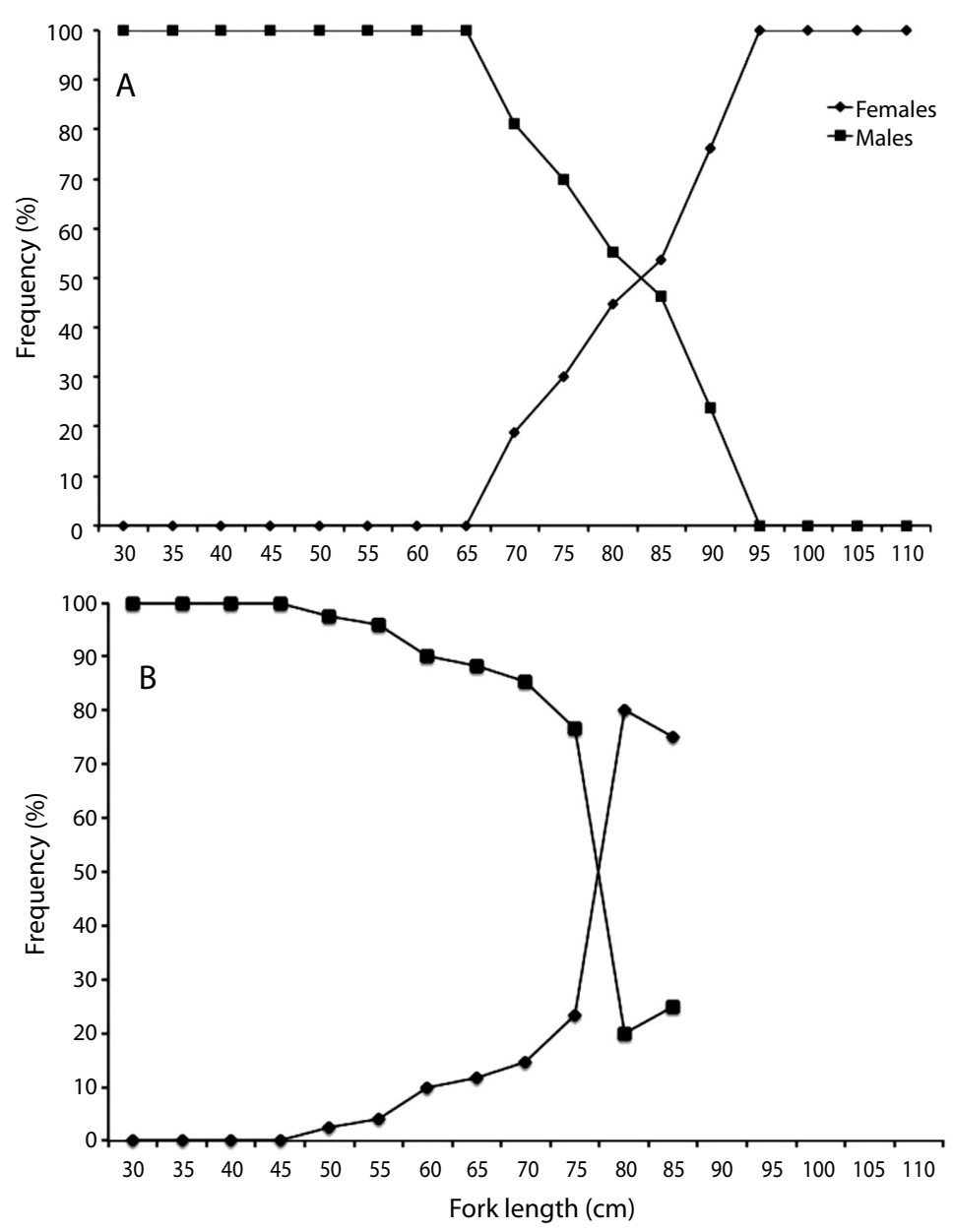

Fig. 3. Sex ratio by length class for the $C$. undecimalis females and males in the coastal (A) and riverine (B) areas, Tabasco, Mexico.

females only in August (25\%) and September $(33.3 \%)$ of 2006.

First gonadic maturity $\left(\mathbf{L}_{\mathbf{5 0}}\right)$. In the coastal area, the size at which $50 \%$ of the population matured $\left(\mathrm{L}_{50}\right)$ was recorded at approximately $60 \mathrm{~cm}$ fork length for males and $80 \mathrm{~cm}$ for females, whereas the size of $100 \%$ of each sex was mature $\left(\mathrm{L}_{100}\right)$ was estimated at $95 \mathrm{~cm}$ for males and $100 \mathrm{~cm}$ for females (Fig. 7A). The average age of sexual maturity $\left(\mathrm{A}_{50}\right)$ was recorded as 5.5 years for males and approximately 8.5 for females (Fig. 7B). Most males were sexually mature at 11 years of age, in contrast, females were mature at approximately 13 years of age. The size and age of first maturity were not estimated for the riverine area, as only organisms in stages II and III were found.

\section{DISCUSSION}

Common snook throughout their range conducts to annual reproductive migrations similar to the patterns we recognize for snooks 


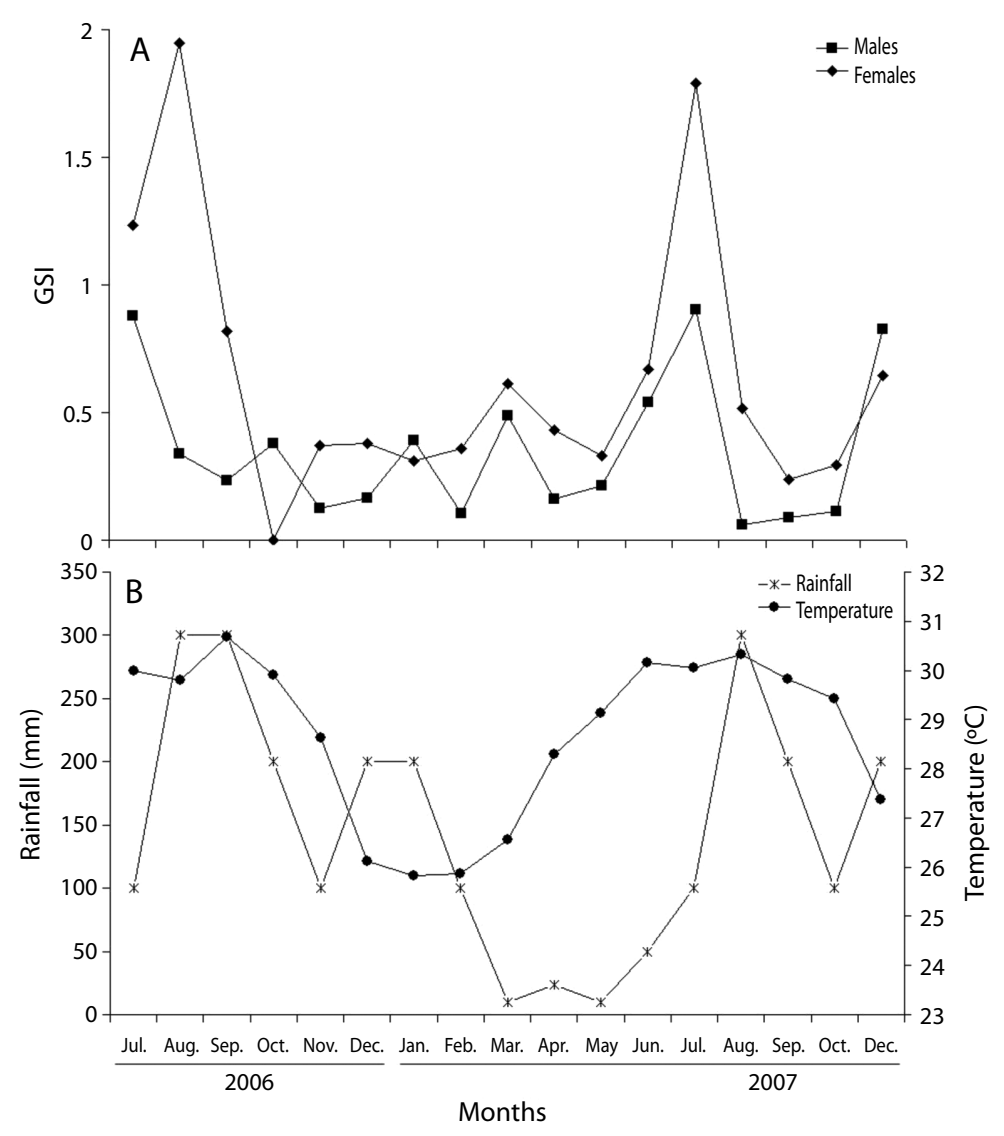

Fig. 4. Monthly variation of the gonadosomatic index (GSI) for C. undecimalis males and females (A), associated with rainfall and temperature $(\mathbf{B})$ in the coastal area, Tabasco, Mexico.

in Tabasco, Mexico (Marshall 1958, Peters et al. 1998, Taylor et al. 2000). Common snook historically occur in the upland rivers, streams, and lakes during the late fall and winter where they find refuge from large marine predators and forage on ample food reserves (Stevens $e t$ al. 2007). Vast schools aggregate in inlets and around the mouths of coastal rivers during the late spring, summer, and early fall to spawn.

However, we found reproduction to occur only in the coastal areas during April to September even though females of mature sizes occur in the riverine areas, they showed no reproductive activity which confirms that spawning and reproduction of $C$. undecimalis takes place in the coastal area (Stevens et al.
2007). Several authors have reported similar results with respect to the reproductive period and spawning sites for common snook (Marshall 1958, Volpe 1959, Gilmore et al. 1983, McMichael et al. 1989, Taylor et al. 1998, Caballero 2003, Perera-Garcia et al. 2008).

Results from this study show that the mean length of females when the sex ratio of the population is $1.46 \mathrm{M}: 1.0 \mathrm{~F}(>80 \mathrm{~cm})$ is larger than that of males. This is a classic response to the reproductive strategy of a protandric hermaphrodite (Sadovy \& Shapiro, 1987, Taylor et al . 2000). Vazzoler (1996) and Devlin \& Nagahama (2002) reported that protandric hermaphroditism is an advantageous reproductive strategy because successful spawning and fecundity 

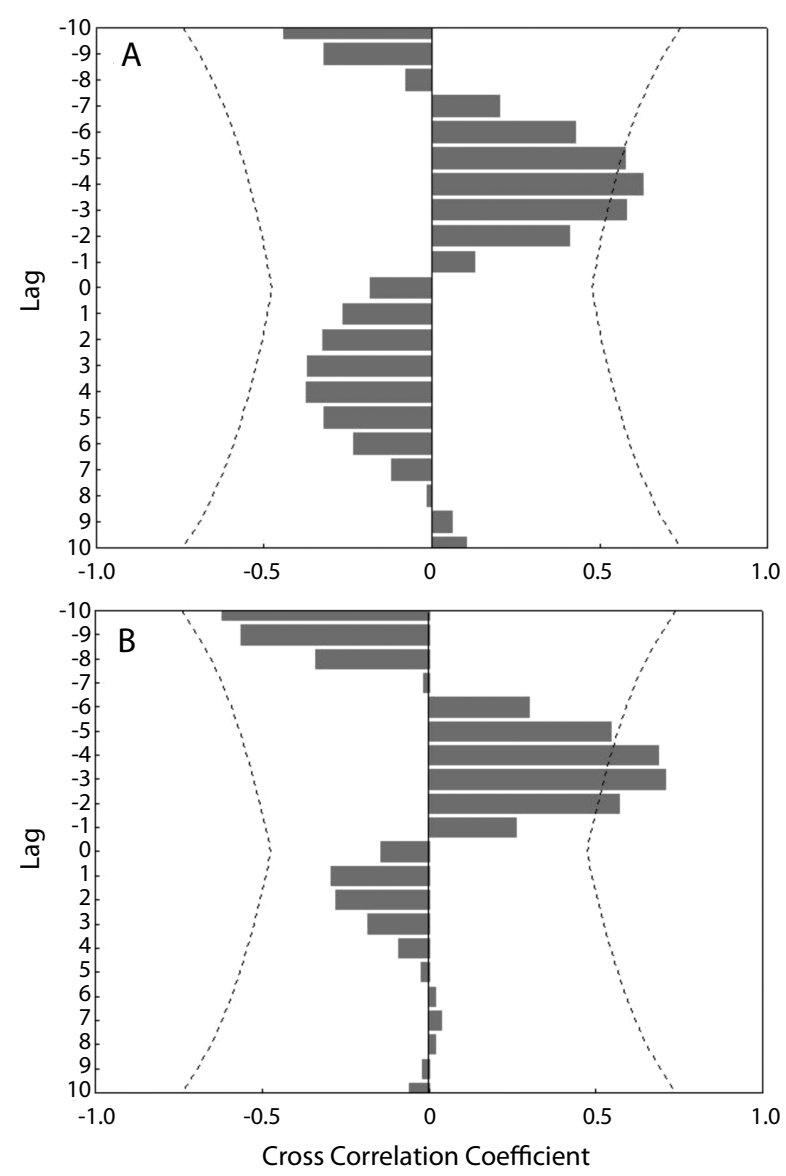

Fig. 5. Cross correlation coefficient for GSI and rainfall for males (A) and females (B), in the coastal area, Tabasco, Mexico.

are of a greater magnitude with higher rates of reproductive success in species with greater lengths than smaller species at comparable ages. Common harvest practices of fishermen along the Usumacinta, San Pedro, and San Pablo rivers take advantage of the reproductive migrations of common snook to collect these larger specimens with nets that obstruct the entire river (Perera-García et al. 2008). Consequently, the wise use of this important resource is in jeopardy because the local fishery focuses on the larger reproductive individuals (Hesp et al. 2004, Sadovy \& Liu 2008).

Both, coastal and riverine areas harbored more males than females; however, larger females were more abundant in the coastal area in comparison with the riverine area. These differences in the sex ratio may be related to reproduction or to sexual differences in growth, migratory habits, or mortality. Selectivity caused by type and size of fishing gear may also affect the collection of larger individual males or females (Viana et al. 2000, Braccini \& Chiaramonte 2002, Siegel et al. 2008); but, specific studies are needed to demonstrate these relationships.

The predominance of small males in the population is a function of the rate of sex reversal in the population; the absence of males in the larger size classes means that reversal is 


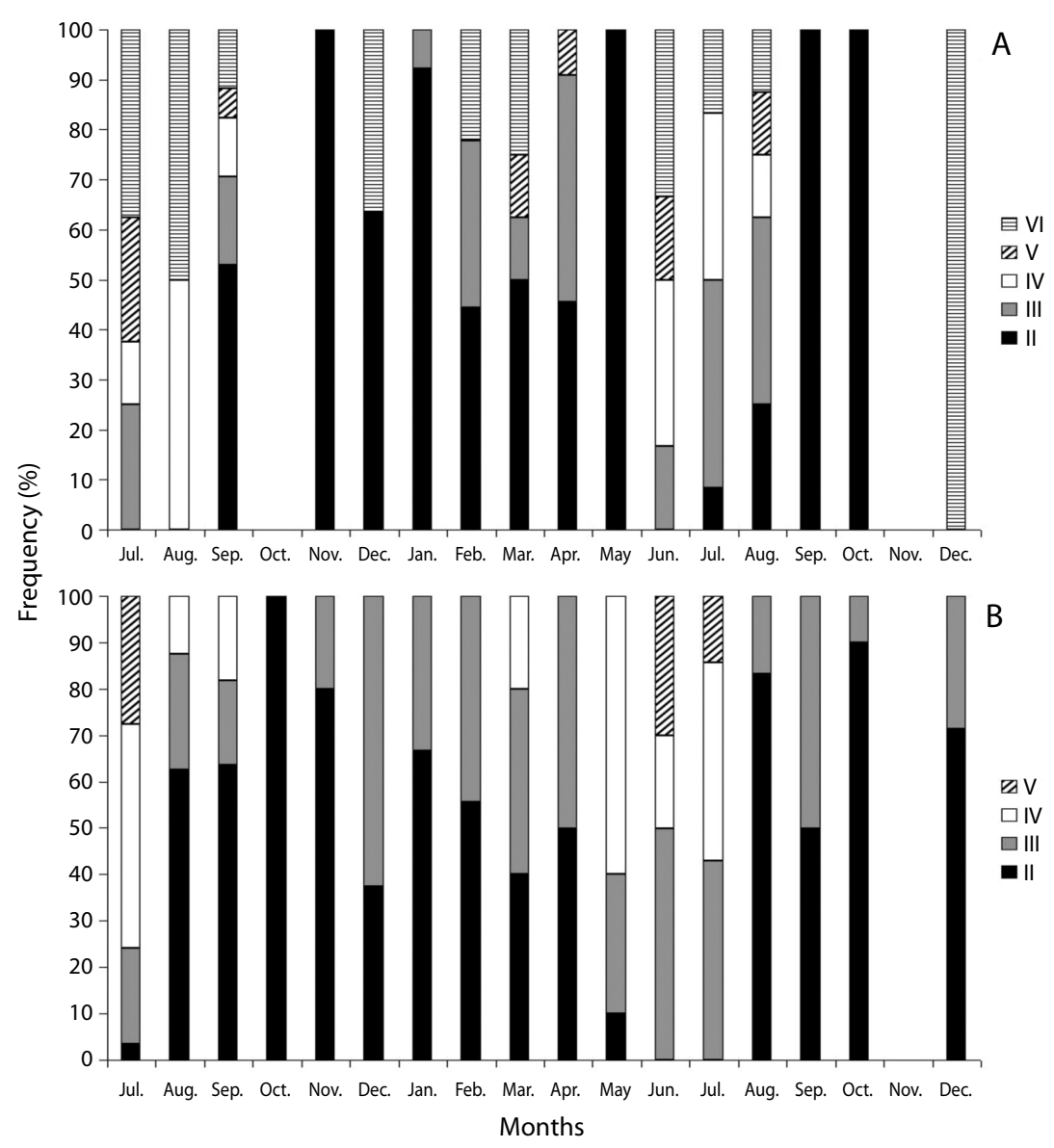

Fig. 6. Relative frequency of the maturity stages for $C$. undecimalis, females (A) and males (B), in the coastal area, Tabasco, Mexico.

obligatory but does not occur simultaneously in all males (Devlin \& Nagahama 2002, Villamil et al. 2002, Hesp et al. 2004).

Common snook is a synchronous spawner and aggregate near or along the coast during the warmer season, when rains initiate the onset of primary production. The timing of these annual events provide additional food resources and habitat for successful recruitment which is characteristic of teleosts of the family Centropomidae (Peters et al. 1998, Taylor et al . 1998, Lozano \& Olaya-Nieto 2004, Alonzo \& Mangel 2005, Maldonado-García et al. 2005).

Various environmental factors may affect the synchrony of the reproductive process, including the temperature, salinity, rainfall and full moons (Peters et al. 1998, Aliaume et al. 2005, Shinozaki-Mendes et al. 2007). According to Wootton (1990), temperature is the most important environmental factor that affects reproduction in fish, as it modulates the dynamics of the gonadal cycle and influences the secretion of gonadotropic hormones.

In this study, $C$. undecimalis was found to spawn from three to four months before the heavy rains when temperatures were 26 to $30^{\circ} \mathrm{C}$. These snooks were stimulated to migrate from the rivers to the estuaries where they form large reproductive groups along the local coastal regions (Peters et al. 1998). Aliaume et al. 

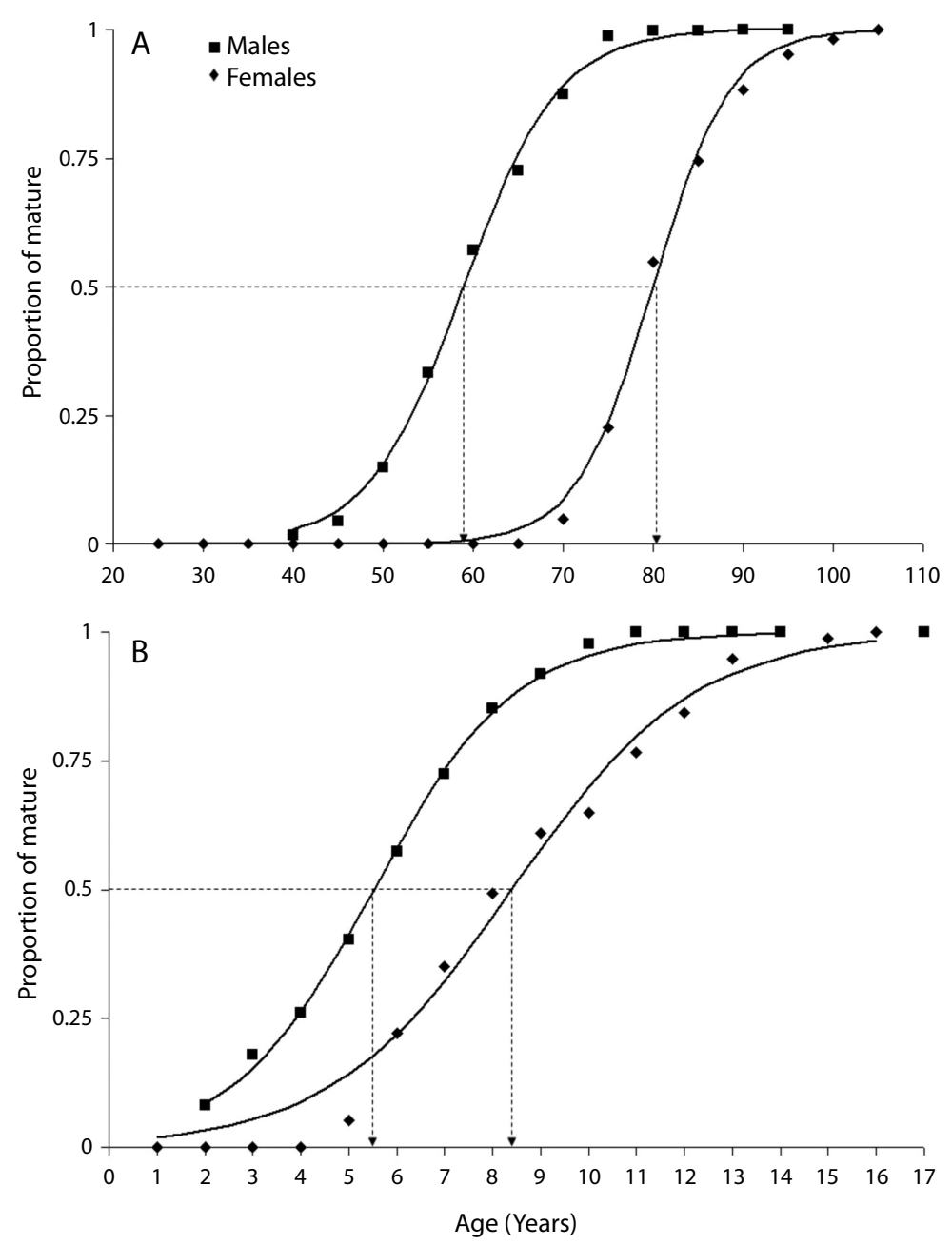

Fig. 7. Length (A) and age (B) at sexual maturity for C. undecimalis males and females, in the coastal area, Tabasco, Mexico.

(2005) reported that the common snook aggregate at or near the onset of the rainy season to insure that the requirements for young-ofthe-year are in place. This strategy guarantees the survival of a greater number of offspring, because there is ample available food for small fish in nutrient-rich areas (Pinheiro 2005, Stevens et al. 2007).

The average size and age of first sexual maturity estimated for $C$. undecimalis in the coastal area were approximately $60 \mathrm{~cm}(5.5$ years) for males, and $80 \mathrm{~cm}$ (8.5 years) for females. These results differ from those reported by Caballero (2003) and Perera-García et al. (2008), but are similar to sizes of snooks in Florida reported by Taylor et al. (2000).

These differences and similarities in ages and sizes at first sexual maturity from different regions may be the result of different selectivity of the gear used to collect the specimens or from differential fishery exploitation (DeMartini et al. 2005, Motta et al. 2005), because 
at high levels of exploitation, larger and older fishes are harvested. Biological effects and/or excessive harvest may lead to a modification of their reproductive strategies: decreasing their $\mathrm{L}_{50}$ and increasing their reproduction effort (Csirke 1993, Kovacic 2004, Perera-García et al. 2008). However, environmental pressures may also play an important part in the changes in these life characteristics, including temperature, latitude, water quality, and flooding cycles that occur along natal rivers (Urriola et al. 2004, Gómez \& Guzmán 2005). The potential effects of inordinate harvest pressure must not be overlooked even though historical sizes and ages at first maturity unknown, we do know that the fishing pressure on common snook has drastically increased in the states of Tabasco and Campeche in recent years (Caballero 2003, Perera-García et al. (2008). Future research should focus on determining the survival rate for the highly exploited common snook in this region.

Then, an understanding of the complete biology of common snook in this region is fundamental to its population equilibrium and successful management. We must conclude a thorough survey of the genetics of the snook population in this region to determine the possible existence of different stocks in the coastal and riverine areas. Future studies, must focus on population dynamics, reproductive biology, migrations, recruitment dynamics, and fishery demographics to ensure that these biological processes remain in balance with harvest rates to insure healthy local stocks.

\section{ACKNOWLEDGMENTS}

The authors thank the fishermen and fishing cooperatives of San Pedro, Barra el Bosque, Tres Brazos and San Pedro Balancán for sharing their data, the Consejo Nacional de Ciencia y Tecnología (CONACyT), the Universidad Juárez Autónoma de Tabasco (UJAT) and the Colegio de la Frontera Sur (ECOSUR) for financing the study. Also, we thank Lenin Árias Rodríguez and Salomón Páramo Delgadillo for their collaboration and comments.

\section{RESUMEN}

En este estudio, se analizó la biología reproductiva y poblacional del robalo blanco (Centropomus undecimalis). El material biológico se obtuvo en los desembarcos de la pesca artesanal de las cooperativas de mayor contribución en la zona costera y ribereña durante julio de 2006 a marzo de 2008. En la zona costera las tallas oscilaron entre 34 a $112 \mathrm{~cm}$ (LF) y en la zona ribereña entre 30 a $85 \mathrm{~cm}$. Se encontraron diferencias significativas entre las longitudes de machos y hembras en ambas zonas de estudio (KruskalWallis, $\mathrm{p}<0.05)$. La proporción machos:hembras fue 1:0.68 en la costa y 1:0.16 para la zona ribereña. La relación longitud-peso no difirió entre sexos en las dos zonas de estudio (ANCOVA, p>0.05). El periodo máximo reproductivo fue de julio a agosto. En la zona costera, se encontró una correlación significativa entre el IGS y precipitación pluvial para machos y hembras $(r=0.63, r=0.70)$, en la zona ribereña solo se encontró un correlación positiva en las hembras $(\mathrm{r}=0.57)$. La talla de primera madurez $\left(\mathrm{L}_{50}\right)$ se estimó a los $60 \mathrm{~cm}$ para hembras y $80 \mathrm{~cm}$ (LF) para machos correspondiendo a 5.5 y 8.5 años de edad respectivamente. Los resultados sugieren un cambio en el periodo de explotación para la conservación de las poblaciones del robalo blanco y su producción.

Palabras clave: pesquería, dinámica poblacional, reproducción, Centropomus undecimalis.

\section{REFERENCES}

Aliaume, C., A. Zerbi \& J.M. Miller. 2005. Juvenile snook species in Puerto Rico estuaries: Distribution, abundance and habitat description. Proc. Gulf Carib. Fish. Inst. 47: 499-519.

Alonzo, S.H. \& M. Mangel. 2005. Sex-change rules, stock dynamics, and the performance of spawning-perrecruit measures in protogynous stocks. Fish. BullNOAA 103: 229-245.

Beamish, R.J. \& G.A. McFarlane. 1983. The forgotten requirement for age validation in fisheries biology. Trans. Am. Fish. Soc. 112: 735-743.

Braccini, J.M. \& G.E. Chiaramonte. 2002. Reproductive biology of Psammobatis extenta. J. Fish. Biol. 61: 272-288.

Brennan, N.P., M.C. Darcy \& K.M. Leber. 2006. Predator-free enclosures improve post-release survival of stocked common snook. J. Exp. Mar. Biol. Ecol. 335: 302-311.

Caballero, C.V. 2003. Estudio biológico pesquero del robalo Centropomus undecimalis en el suroeste de 
Campeche. Tesis de Maestría, Universidad Nacional Autónoma de México, México, D.F., México.

Campana, S.E. 2005. Otolith science entering the $21^{\text {st }}$ century. Mar. Freshwater Res. 56: 485-495.

Csirke, J. 1993. Introducción a la dinámica de poblaciones de peces. FAO, Roma, Italia.

DeMartini, E.E., A.M. Friedlander \& S.R. Holzwarth. 2005. Size at sex change in protogynous labroids, prey body size distributions, and apex predator densities at NW Hawaiian atolls. Mar. Ecol. Prog. Ser. 297: 259-271.

Devlin, H.D. \& Y. Nagahama. 2002. Sex determination and sex differentiation in fish: an overview of genetic, physiological, and environmental influences. Aquaculture 208: 191-364.

Gilmore, R., C. Donohoe \& D. Cooke. 1983. Observations on the distribution and biology of east-central Florida populations of the common snook, Centropomus undecimalis (Bloch). Fla. Sci. 46: 313-336.

Gómez, G. \& R. Guzmán. 2005. Aspectos de la dinámica reproductiva y poblacional del roncador, Micropogonias furnieri, en el golfo de Paria, estado Sucre, Venezuela. Zootecnia Trop. 23: 69-90.

Gulland, J.A. 1983. Fish stock assessment: a manual of basic methods. FAO, Wiley, Chichester, United Kingdom.

Hesp, S.A., I.C. Potter \& G.N. Hall. 2004. Reproductive biology and protandrous hermaphroditism in Acanthopagrus latus. Environ. Biol. Fish. 70: 257-272.

Ibañez, A.A.L. \& B.L.A. Fernández. 2006. Manual técnico de crecimiento relativo y análisis morfométrico. Universidad Autónoma Metropolitana, México, D.F., México.

Kovacic, M. 2004. Reproductive biology of the striped goby, Gobius vittatus (Gobiidae) in the northern Adriatic Sea. Sci. Mar. 71: 145-151.

Lau, S.R. \& P.L. Shafland. 1982. Larval development of snook, Centroponus undecimalis (Pisces: Centropomidae). Copeia 3: 618-627.

Lowerre-Barbieri, S.K., F.E. Vose \& J.A. Whittington. 2003. Catch-and-release fishing on a spawning aggregation of common snook: does it affect reproductive output. T. Am. Fish. Soc. 132: 940-952.

Lozano, G.E. \& C.W. Olaya-Nieto. 2004. Reproductive aspects of common snook (Centropomus undecimalis) in the Cispata Bay, Colombia. Proc. Gulf Carib. Fish. Inst. 55: 1029.

Luksenburg, J.A. \& T. Pedersen. 2002. Sexual and geographical variation in life history parameters of the shorthorn sculpin. J. fish. Biol. 61: 1453-1464.

Maldonado-García, M., V. Gracia-López, M. Carrillo, A. Hernández-Herrera \& C. Rodríguez-Jaramillo. 2005. Stages of gonad development during the reproductive cycle of the blackfin snook, Centropomus medius Günther. Aquacult. Res. 36: 554-563.

Marshall, A.R. 1958. A survey of the snook fishery of Florida, with studies of the biology of the principal species, Centropomus undecimalis (Bloch). Fla. Board Conserv. Mar. Res. Lab. Tech. Ser. 22.

McMichael, R.H., K.M. Peters \& G.R. Parsons. 1989. Early life history of the snook, Centropomus undecimalis in Tampa Bay, Florida. Northeast Gulf Sci. 10: 113-126.

Motta, F.S., O.B.F. Gadig \& R.C. Namora. 2005. Size and sex compositions, length weight relationship, and occurrence of the Brazilian sharpnose shark, Rhizoprionodon lalandii, caught by artisanal fishery from southeastern Brazil. Fish. Res. 74: 116-126.

Muller, R.G. \& R.G. Taylor. 2006. The 2006 stock assessment update of common snook, Centropomus undecimalis. Florida Marine Research Institute. St. Petersburg, Florida, USA.

Perera-García, M.A., M. Mendoza-Carranza \& S. PáramoDelgadillo. 2008. Dinámica reproductiva y poblacional del robalo Centropomus undecimalis, en Barra San Pedro, Centla, México. Universidad y Ciencia 24: 49-59.

Peters, K.M., R.E. Matheson \& R.G. Taylor. 1998. Reproduction and early life history of common snook, Centropomus undecimalis (Bloch), in Florida. Bull. Mar. Sci. 62: 509-529.

Pinheiro, P.R. 2005. Aspectos reprodutivos do robalo peba, Centropomus parallelus, na foz do rio doce, Linhares/es. Master Tesis, Universidade Federal do Espírito Santo, Vitória, Brasil.

Pyper, B.J. \& R.M.Peterman. 1998. Comparison of methods to account for autocorrelation in correlation analyses of fish data. Can. J. Fish. Aquat. Sci. 55: 2127-2140.

Ricker, W.E. 1975. Computation and interpretation of biological statistics of fish populations. B. Fish. Res. Board Can. 191: 1-382. 
Rodríguez-Gutiérrez, M. 1992. Técnicas de evaluación cuantitativa de la madurez gonádica en peces. AGT, México, D.F., México.

Sadovy, M.Y. \& M. Liu. 2008. Functional hermaphroditism in teleosts. Fish Fish. 9: 1-43.

Sadovy, M.Y. \& D.Y. Shapiro. 1987. Criteria for the diagnosis of hermaphroditism in fishes. Copeia: 136-156.

SAGARPA, 2008. Anuario Estadístico de Pesca 2008. Secretaría de Agricultura, Ganadería, Desarrollo Rural, Pesca y Alimentación, México, D.F.

Shinozaki-Mendes, R.A., F.H.H. Vieira, P.O. Guilherme \& F.C. Correia. 2007. Reproductive biology of the squirrelfish, Holocentrus adscensionis (Osbeck, 1765), caught off the coast of Pernambuco, Brazil. Sci. Mar. 71: 715-722.

Siegel, V., U. Damm \& T. Neudecker. 2008. Sex-ratio, seasonality and long-term variation in maduration and spawning of the brown shrimp Crangon crangon (L.) in the German Bight (North Sea). Helgon Mar. Res. 63: 339-349.

Sokal, R.R. \& F.J. Rohlf. 1996. Biometry: The Principles and Practice of Statistics in Biological Research. Freeman, New York, USA.

Sparre, P. \& S.C. Venema. 1998. Introducción a la evaluación de recursos pesqueros tropicales, Parte 1 manual. FAO, Santiago de Chile, Chile.

Stevens, P.W., D.A. Blewett \& G.R. Poulakis. 2007. Variable habitat use by juvenile common snook, Centropomus undecimalis (PISCES: CENTROPOMIDAE): Applying a life-history model in a southwest Florida estuary. B. Mar. Sci. 80: 93-108.

Tavares, L.E.R. \& J.L. Luque. 2003. A new species of Acantholochus (Copepoda: Bomolochidae) parasitic on Centropomus undecimalis (Osteichthyes: Centropomidae) from the coastal zone of the State of Rio de Janeiro, Brazil. Mem. Inst. 98: 241-245.

Taylor, G.R., H.J. Grier \& J.A. Witthington. 1998. Spawning rhythms of common snook in Florida. J. Fish. Biol. 53: 502-520.

Taylor, G.R., J.A. Wittington \& H.J. Grier. 2000. Age growth, maduration and protandric sex reversal in the common snook Centropomus undecimalis, from the east and west coasts of south Florida. Fish. Bull. 98: 612-624.
Tringali, M.D. \& K.M. Leber. 1999. Genetic considerations during the experimental and expanded phases of snook stock enhancement. Bull. Natl. Res. Inst. Aquacult. Suppl. 1: 109-119.

Tucker, J.W. \& S.W. Campbell. 1988. Spawning season of common snook along the central Florida coast. Florida Scientist. Q. J. Fla. Acad. of Sci. 51: 1-6.

Underwood, A.J. 1997. Experiments in ecology. Their logical design and interpretation using analysis of variance. Cambridge University, Cambridge, United Kingdon.

Urriola, M.H., P.J. Cabrera \& Q.M. Protti. 2004. Composición, crecimiento e índice de condición de una población de Poecilia reticulata (Pisces: Poeciliidae), en un estanque en Heredia, Costa Rica. Rev. Biol. Trop. 52: 157-162.

Vazzoler, A.E.A. 1996. Biologia da reprodução de peixes teleósteos: Teoria e prática. Maringá, São Paulo, Brasil.

Viana, F.A., A. Acuña \& E. Danulat. 2000. Testes morphology and reproductive aspects of male Brazilian codling (Urophycis brasiliensis Kaup, 1858). J. Appl. Ichthyol. 16: 134-135.

Villamil, M.M., J.M. Lorenzo, J.G. Pajuelo, A. Ramos \& J. Coca. 2002. Aspects of the life history of the salema, Sarpa salpa (Pisces, Sparidae), off the Canarian Archipelago (central-east Atlantic). Environ. Biol. Fish. 63: 183-192.

Volpe, A. 1959. Aspects of the biology of the common snook Centropomus undecimalis (Bloch) of southwest Florida. Tech. Ser. Fla. Bd. Conserv. 37: 1-37.

Wootton, R.J. 1990. Ecology of teleost fishes. Chapman and Hall, Londres, Inglaterra.

Zar, J.H. 1999. Biostatistical Analysis. Prentice-Hall, New Jersey, USA.

Zar, J.H. 1999. Biostatistical analysis. Fourth edition. Prentice Hall, Englewood Cliffs, New Jersey, USA.

Zarza-Meza, A.E., J.B. Villalobos, C.P. Vásquez \& P.T. Álvarez. 2006. Cultivo experimental del robalo Centropomus undecimalis (Bloch, 1792) y chucumite Centropomus parallelus (Poey, 1860) (Perciformes: Centropomidae) en agua dulce en un estanque de concreto en Alvarado, Veracruz, México. Vet. Méx. 37: 327-333. 